JEL classification: M5

DOI: https://doi.org/10.46361/2449-2604.8.3.2021.23-30

\section{TEONA MAISURADZE}

\section{Assistant professor,}

Georgian National University,

Tbilisi, Georgia

Email: teo.maisuradze3@gmail.com

https://orcid.org/0000-0003-4597-5736

Edited by:

November, 2021

Reviewed by:

December, 2021

\section{ORGANIZATIONAL STRESS ON THE WORKPLACE: ITS} IMPACT ON EMPLOYEES AND ORGANIZATIONS

The workplace has never been as stressful as it is today. It has different and uncommon challenges nowadays. First of all, with the passage of time, knowledge becomes obsolete faster, constant improvement of skills and continuous professional growth becomes necessary. The spread of COVID19 worldwide in 2020 has made organizational stress issue more pressing. Rising unemployment rate and job shedding have led to a sharp rise in stress levels among employed people. The nature of most of the work has changed, with some moving to a remote and part to a hybrid work model. It is not new that high level of organizational stress is directly related to productivity. When the stress level is high, the risk of making mistakes increases, the level of innovation is low, job satisfaction decreases, a problem of communication and dissemination of correct information occurs, which finds its reflection in increased in turnover, absences, etc. These events significantly reduce a person's ability to work, labor productivity decreases; therefore, it is not possible to fully utilize the potential of the organization.

Keywords: stress management, organizational stress, pandemic. 
JEL classification: M5

DOI: https://doi.org/10.46361/2449-2604.8.3.2021.23-30

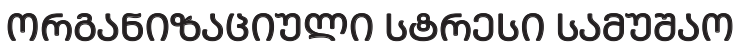

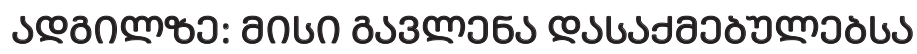

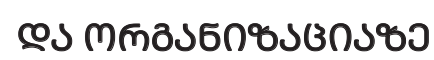

\section{ตวตธง วงกเทต่งdว}

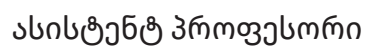

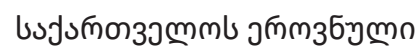

ทธกววต์เภิวฮిก,

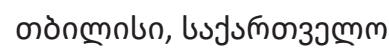

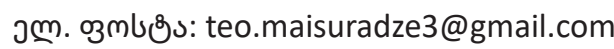
https://orcid.org/0000-0003-4597-5736

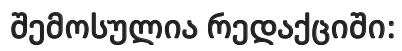

Бмวдљวณо, 2021

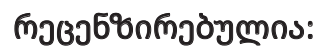

œวзวдљюо, 2021

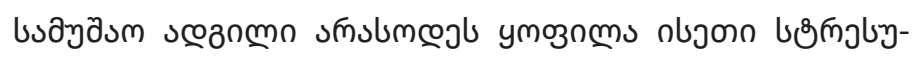

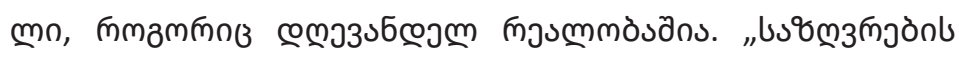

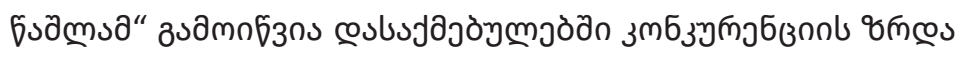

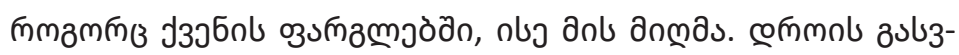

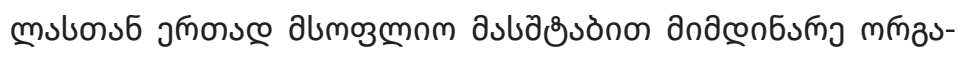

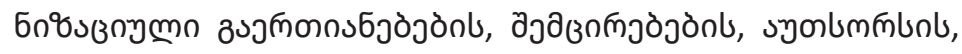

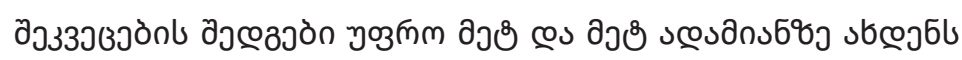

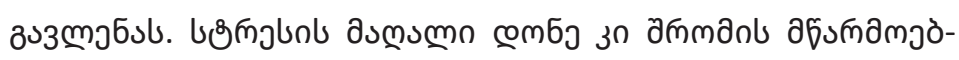

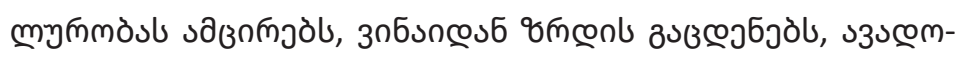

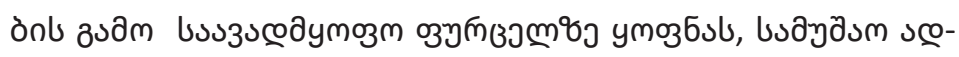

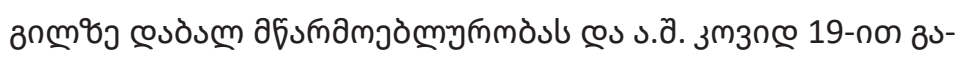

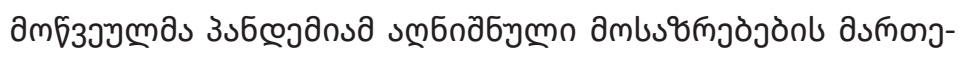

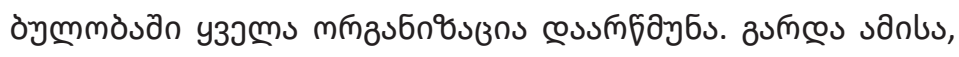

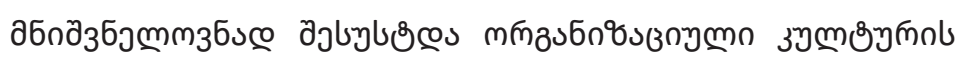

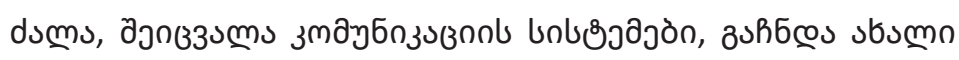

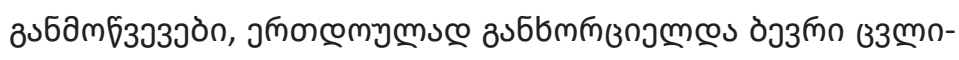

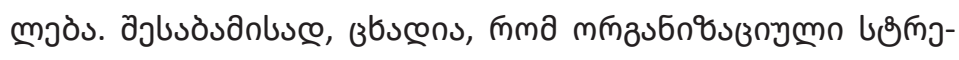

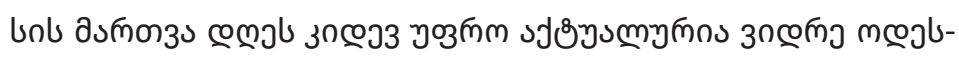

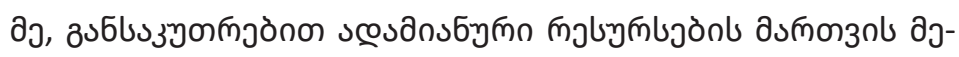

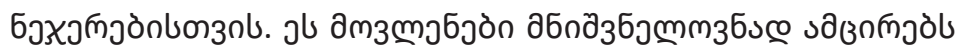

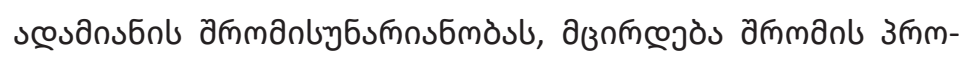

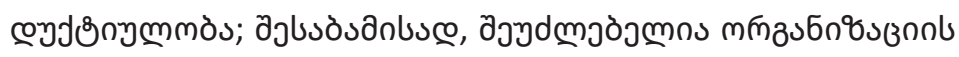

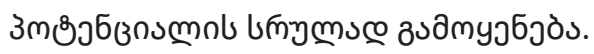

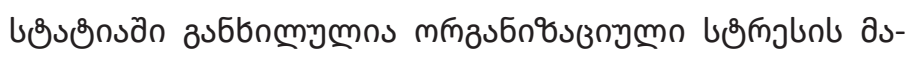

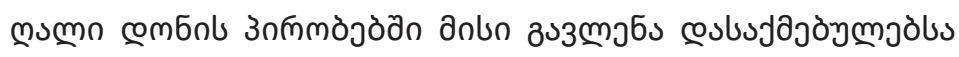

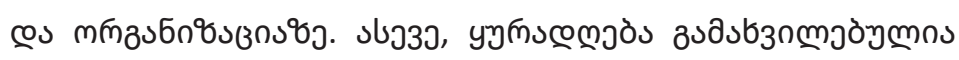

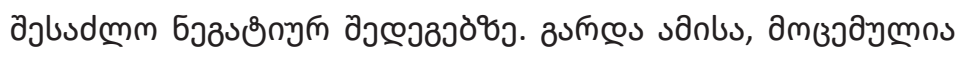

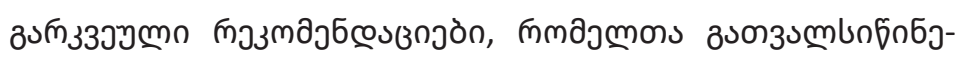

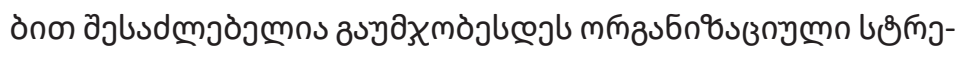
unb asmozol bsmolvon.

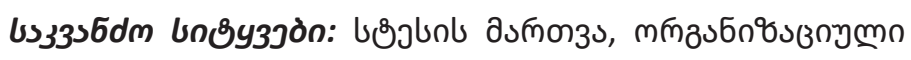

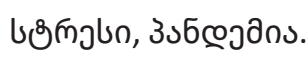

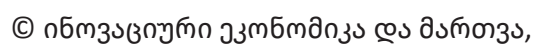

2021 


\section{INTRODUCTION}

Stress is an inevitable part of work life, which is why it is often the subject of study and observation by researchers in various disciplines. It is found among employees of organizations operating in both developing and developed countries. High levels of stress have a negative impact on a person. Chronic stress can «burnout» a person and cause serious damage to his health. Clearly, in this case the employee will no longer be productive for the organization and will not be able to make an appropriate level of contribution to the achievement of strategic goals. Consequently, for business stakeholders, this is a very topical event.

The importance of employee health, wellbeing and stress has been made even more urgent by the 2020 pandemic. No industry is stress free, but some face with it more than the others. Most organizations have tried to continue to function normally and avoid complications caused by pandemics through remote work. The traditional 'work around the clock' concept has subjected to a paradigm shift on account of alternative work timings and patterns of the twenty first century work environment. Work today is 'result oriented' rather than 'people oriented' [1]. However, this proved impossible for the majority of people, mainly employed in the manufacturing sector. Consequently, this sector still faces a significant challenges. For example, the second year in a row, enterprises have been forced to compensate isolation to the employees, except hospitalization or infection with Covid19. If infected/isolated person works in shifts, employee who is working instead of him at overtime is under the risk of increasing stress level, burnout and have negative impact on his health. Constant labor shortages reduce the labor productivity of current employees as well. The main problem in Georgia is that people face with all organizational problems without preparation.

\section{UNDERSTANDING STRESS - LITERATURE REVIEW}

There are different definitions of the workplace stress. For example, Jeremy stranks defines it as following: 'work stress is a psychological state which can cause an individual to behave dysfunctional at work and results from people's response to an imbalance between job demands and their abilities to cope'. It arises when people try to cope with tasks, responsibilities or their forms of pressure connected with their jobs, but encounter difficulty, strain, anxiety and worry in endeavoring to cope. [2] Tatyana Khutornianskaia sum ups, that occupational stress can be defined as a stressful state of an employee that occurs when he is exposed to emotionally negative and extreme factors associated with his professional activity. She shares the classical definition given by Selye, that stress is a complex of nonspecific adaptive reactions of the organism to any demands made upon it due to the influence of stress factors that have entailed a violation of its homeostasis. Nonspecific reactions are adaptive actions aimed at restoring the initial state of the body, produced by specific effects on specific stimuli [3]. People experience stress differently based on the individual reasons. All persons have their own life path and own perception of an event or situation. Scientists differ two types of a stress. First, when human views a situation negatively, he/she will likely feel distressed-overwhelmed, oppressed, or out of control. Distress is the more familiar form of stress. The other form, eustress, results from a "positive" view of an event or situation, which is why it is also called "good stress."[4] Eustress results can be stimulating, thus enhancing work performance and positively encouraging workers to make efforts.[5] 


\section{WORKPLACE STRESS IMPACT ON THE EMPLOYEES}

Workplace stress is defined by free medicine dictionary as "work-related mental tension, relationships at work, organizational structure and climate. How all these will be perceived is depended on the individual characteristics of the individual like level of anxiety, neuroticism,

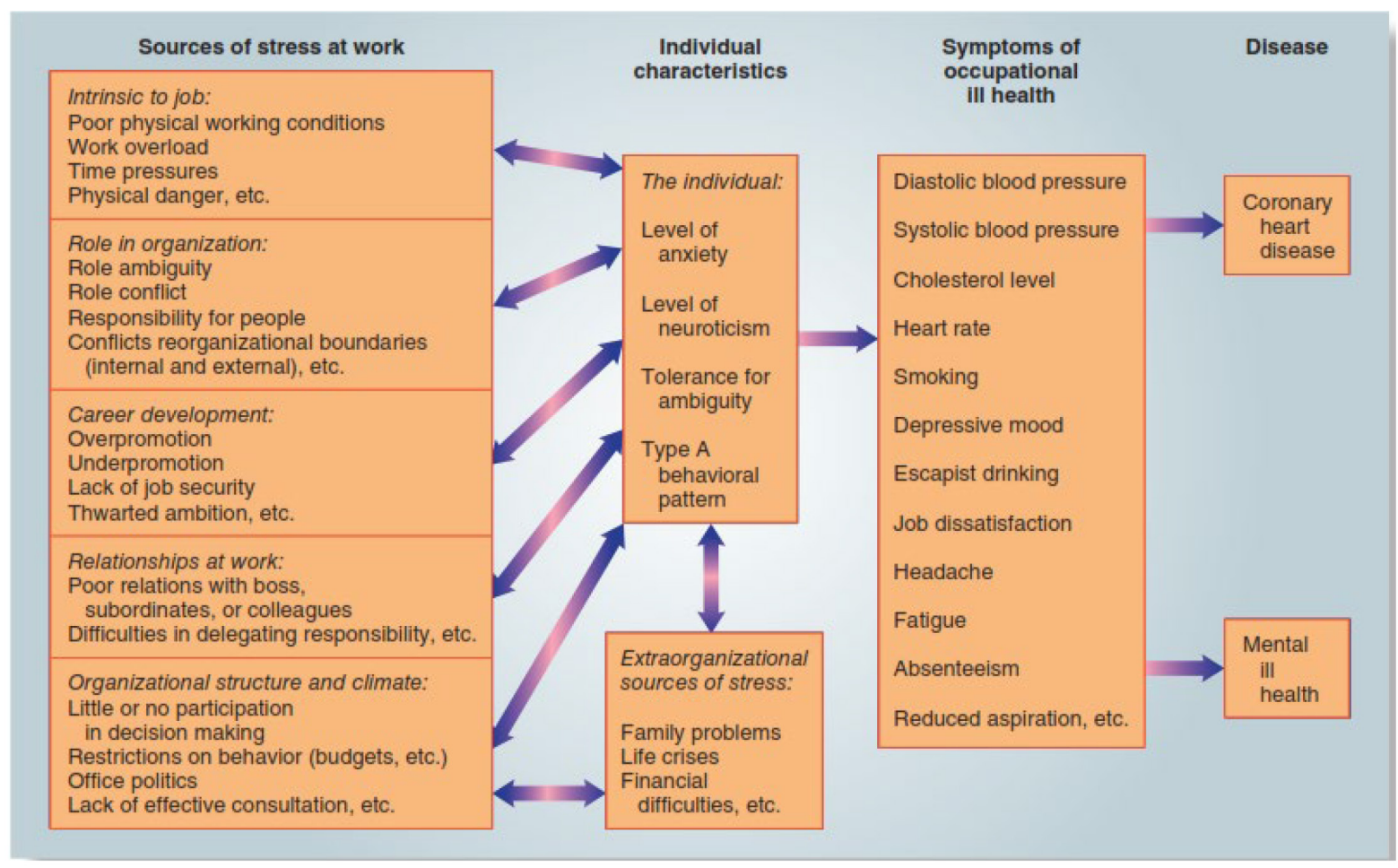

Figure 1. Workplace stress model [10]

which causes exhaustion, insomnia, muscle pain, depression, and eventually job burnout." And itself burnout is defined as emotional and physical exhaustion resulting from a combination of exposure to environmental and internal stressors and inadequate coping and adaptive skills. In addition to signs of exhaustion, the person with burnout exhibits an increasingly negative attitude toward his or her job, low self-esteem, and personal devaluation. [6] But when an employee can manage the pressures of the job and the possibility to complete a task is substantial, then stress can work as a motivating factor [7].

At the workplace there are different types of stress sources, which can be related to Intrinsic to job, Role in Organization, Career development, tolerance of ambiguity and a behavioral patter. But all these are affected by extra organizational sources of stress which itself affect on sources of stress at work. Based on the mentioned factors, different symptoms of occupational health is appeared for each employee. As a result mental health or coronary hear diseases can be caused. (Figure 1) [10]. As workplace stress can have so negative impact on employees, towards the end of Millennium, attention was paid to the time spent at work by the individuals. Accordingly, the necessity of being happy at work became new subject of interest. The strategic approach's main goals have resulted in positive outcomes for smoke-free workplaces with handicapped access; nonetheless, the vision of psychologically 
better workplaces has been formed but not yet fulfilled. The HSE management have standards which are a systematic endeavor to guarantee that organizations follow recommendations on psychosocial working variables, such as workload and management practices, in order to «reflect a high degree of health well-being and organizational success» (HSE, 2009). There are the six dimensions addressed by the guidelines: Demands, Control, Support, Relationships, Role, and Change.[8]. Managers should consistently evaluate weaknesses and difficulties organization holds in order for them to have an objective perception of reality [19].

\section{WORKPLACE STRESS IMPACT ON THE ORGANIZATIONS}

Workplace stress causes negative effects to the whole organization. When employee is under high stress, his/her normal functionality is limited. He can hardly perform his duties and performance quality is quite low. Thus, we can consider that workplace stress reduces organizational productivity as a whole. This issue is very actual nowadays and a lot of researches are conducted to investigate reasons, connection between different organizational factors and find out best possible recommendations. For example, Oboreh O.E and Okeke M.N have conducted research about the impacts of stress on staff productivity in five banks in Awka, Anambra State in 2016. The study discovered that the most significant effect of work-related stress on an organization is a decrease in productivity. Employees that are stressed are far less likely to devote their efforts to continuous improvement or innovative issue solution. Individuals who are coping with stress and are in self-preservation mode prefer to spend their time and energy doing the absolute minimum to keep up. Furthermore, an overworked team will have less energy to begin with, as stress depletes energy storage as well as a person's physical and mental skills, according to research.[5]. Kumar G.G.S and Joy A.J have conducted the research in Kerala among the software professionals in 2018. Their findings was unsurprisingly the same, job stress was reducing the productivity. New finding in this study was that they defined that the job performance of the software professionals is dependent on role ambiguity, salary and rewards, fear of obsolescence and workload.[9].

The costs of occupational stress to the organizations are primarily related to sickness and absenteeism, reduced productivity, worker replacement costs and training, and additional retirement costs. There may be further costs due to damage in production or equipment, costs in connection with grievance and litigation, and a potential public loss of goodwill toward the organization. [10] Ongori and Agola, 2008 based on their study findings claim that, the outcomes associated with the occupational stress adversely affect the organization, especially in reducing efficiency in organization operations, increasing employee turnover, and the expenditure of health costs of employees, low motivation and accidents. The study findings also confirmed that occupational stress costs are high and its impact on employees cannot be ignored. Organizational failure to manage occupational stress might erode the organizational profitability through litigation, morbidity and mortality [11].

\section{MANAGING WORKPLACE STRESS}

As it was shown above, high organizational stress have negative impact on both: organizations and the employees. It is obligatory from organizations to identify stressors and predict the stress increase in order to avoid escalation of situation. Employers have a responsibility (both legally and morally) to ensure that the mental health and wellbeing of their workers is not being 
adversely affected by their roles. By developing and implementing framework to support and cultivate workplace cultures that understand the importance of workplace stress, employers can demonstrate their commitment to their team's mental health and wellbeing and maintain team performance and attendance [12]. One of the best models for managing the organizational stress can be Scandinavian model (Figure 2).
Working conditions should provide opportunities for personal and vocational development, as well as for self determination and professional responsibility

Paruk N, 2010 shares her findings the literature has suggested and claims that in order to have a healthy organization who copes with stress effectively, there should to be a match between workers expertise and needs, an effective

Working conditions are adapted to people's differing physical and mental aptitudes

Employee is given the opportunity to participate in the design of his/her own work situation, and in the processes of change and development affecting his/her work

Technology, work organisation, and job content are designed so that the employee is not exposed to physical or mental strains that may lead to illness or accidents. Forms of remuneration and the distribution of working hours are taken into account

Closely controlled or restricted work is avoided or limited

Work should provide opportunities for variety, social contact, and cooperation as well as coherence between different working operations

Working conditions should provide opportunities for personal and vocational development, as well as for self determination and professional responsibility

Figure 2. Principles of preventing work stress in Scandinavia [13]

Working conditions are adapted to people's differing physical and mental aptitudes

Employee is given the opportunity to participate in the design of his/her own work situation, and in the processes of change and development affecting his/her work

Technology, work organisation, and job content are designed so that the employee is not exposed to physical or mental strains that may lead to illness or accidents. Forms of remuneration and the distribution of working hours are taken into account

\section{CLOSELY CONTROLLED OR RESTRICTED WORK IS AVOIDED OR LIMITED}

Work should provide opportunities for variety, social contact, and cooperation as well as coherence between different working operations management and reward system should exist, employee empowerment and involvement as well as support for the domestic and family needs of the worker as well as a balance between the needs of all stakeholders should be taken into consideration [14].

\section{CONCLUSION}

To sum up, its visible how big effect can the stress have for both employees and organizations. Among the problems which are subject of researchers' interest organizational stress is the most important one as it is directly connected to the mental condition of the humans and can finish with strong depression or even suicide [15]. Nowadays situation gets worse as managers hardly take attention the stress prediction and 
prevention. Stressed employees can hardly be engaged and struggle to focus on their performance at work. Due to low performance, likelihood of their involvement in conflict situations increases. As managers rarely involve in managing conflicts. Frequently conflict party leaves organization after this, but if he/she stays it will increase his/her stress level due to the not overcoming conflict sources existence. [16] Thus, organizations should take care about employee well-being more. They should achieve employee job satisfaction as it affects a number of organizational behaviors and can greatly determine employee wellbeing [20]. In new reality they especially need to maintain employee behavior which supports the new organizational strategy, reality and daily functioning. [17] Managers have to deal with more and more difficult tasks on a daily basis, as the diversity of the workforce makes it more difficult to combine them to achieve synergy [21]. Positive aspect in the new normal era is that people has realized that we are all together in the pandemic reality, what touches one person, touches another too [18]. Increasing awareness and taking care about well-being activities can be solution to decrease stress level and its impact on productivity.

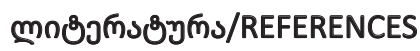

[1]. Joy A.J, Kumar G.G.S., "Impact of job Stress on Employee Performance: A Study of Software Professionals in Kerala", 2018 IJRAR October 2018, Volume 5, Issue 4, pgs. 694-715

[2] Stranks J., "Stress at work, management and prevention", Oxford, Great Britain, 2005, ISBN 0750665424

[3] Khutorinskaia T., PROFESSIONAL STRESS AND GENERAL REGULARITIES OF ITS MANIFESTATION, OБPA3OBAHИE В СОВРЕМЕННОМ МИРЕ, Сборник научных статей. Саратов, 2019

[4] University of Akron, "INTRODUCTION TO STRESS MANAGEMENT", Retrieved from https://www.uakron.edu/ armyrotc/MS1/14.pdf on 01.11.2021

[5] Okeke, M. N; Oboreh, O. J. C, EFFECTS OF STRESS ON EMPLOYEE PRODUCTIVITY, International Journal of Accounting Research (IJAR) Vol. 2, No. 11, 2016, pgs. 38-49

[6] https://medical-dictionary.thefreedictionary.com/burnout Retrieved on 01/11/2021

[7] Halkos, G. E. \& Dimitrios, B. (2008). The influence of stress and satisfaction on productivity. MPRA Paper No. 39654, 1 - 26.

[8] Ashley Weinberg, V. J. ORGANIZATIONAL STRESS MANAGEMENT. PALGRAVE MACMILLAN, 2010. Pgs. 311

[9] Kumar G.G.S and Joy A.J, Impact of job Stress on Employee Performance: A Study of Software Professionals in Kerala, IJRAR October 2018, Volume 5, Issue 4, www.ijrar.org (E-ISSN 2348-1269, P- ISSN 2349-5138)

[10] Greenberg J.S, Comprehensive Stress Management, McGraw-Hill Education, 2 Penn Plaza, New York, NY 10121, 2017, pgs. 481

[11] Ongori H., Agolla J, Occupational Stress in Organizations and Its Effects on Organizational Performance, Retrieved on 10/11/2021 from https://www.researchgate.net/publication/288845360_Occupational_stress_ in_organizations_and_its_effects_on_organizational_performance

[12] Masterinmind. (2021). Managing and reducing workplace stress. Retrieved from 
https://www.matesinmind.org/media/luqp1yjx/managing-and-reducing-workplace-stress-handbook.pdf

[13] Michie S., CAUSES AND MANAGEMENT OF STRESS AT WORK, Occup Environ Med 2002; pgs., 67-72.

[14] Paruk N., Stress Management amongst Bank Executives: A case study, A dissertation submitted in partial fulfilment of the requirements for the degree of Master of Business Administration, UNIVERSITY OF KWAZULUNATAL, 2010.

[15] Robinson B., Grappling With The Rise Of Work-Related Suicide During The Pandemic: How To Support Yourself And Fellow Coworkers, Retrieved on 20/11/2021 from https://www.forbes.com/sites/bryanrobinson/2020/09/05/ grappling-with-the-rise-of-work-related-suicide-during-the-pandemic-how-to-support-yourself-and-fellowcoworkers/?sh=254e3a948d24

[16] Paresashvili N., Maisuradze T., Gechbaia B., Weis L., Koval V., Conflict management impact on the employee productivity, SHS Web of Conferences 111, 01010 (2021), EECME 2021, https://doi.org/10.1051/ shsconf/202111101010

[17] Maisuradze T., Covid19's Impact on Talent Management: New HR Challenge, 2021 International CEO Communication, Economics, Organization \& Social Sciences Congress. http://www.ceocongress.org/files/E-book/2021\%20CEO\%20Proceedings\%20Book.pdf?_t=1630446280

[18] Nadjafova Z., Paresashvili N., Maisuradze T., Nikvashvili M., ORGANIZATIONAL CONFLICT MANAGEMENT DURING COVID 19, 70th International Scientific Conference on Economic and Social Development - Baku, 2526 June, 2021

[19] Paresashvili N., Gurbanov N., Gechbaia B., Goletiani K., Edzgveradze T, Significant issues of organizational conflict management, Economic and Social Development: Book of Proceedings, Varazdin Development and Entrepreneurship Agency (VADEA), 2020, Pgs. 457-464

[20] Paresashvili N., Okruashvili N., Chitaladze K., THE NEED fOR CROSS-CULTURAL COMPETENCIES IN A MULTICULTURAL ENVIRONMENT, Conference INTED2021, Volume 1, ISBN: 978-84-09-27666-0; ISSN: 23401079, Pages 9946-9952

[21] Paresashvili N., Edzgveradze T, Job satisfaction in the context of organizational behavior, Conference ДВНЗ «Київський національний економічний університет імені Вадима Гетьмана», 2019, pgs. 375-379 